Unnes Journal of Public Health

\title{
EVALUASI INPUT SISTEM SURVEILANS DEMAM BERDARAH DENGUE DI DINAS KESEHATAN KAB. TEGAL
}

\author{
Maulana Mufidz ${ }^{\bowtie}$ \\ Jurusan Ilmu Kesehatan Masyarakat, Fakultas Ilmu Keolahragaan, Universitas Negeri \\ Semarang, Indonesia
}

\section{Info Artikel}

Sejarah Artikel: Diterima

Januari 2015 Disetujui

Januari 2015

Dipublikasikan April

2016

Keywords:

DHF; District Health Office;

evaluation; surveillance

\begin{abstract}
Abstrak
Surveilans DBD merupakan salah satu kegiatan dalam pencegahan dan pengendalian kasus DBD. Tujuan penelitian untuk mengetahui input sistem surveilans Demam Berdarah Dengue di Dinas Kesehatan Kab. Tegal. Jenis penelitian deskriptif dengan pendekatan kualitatif dan desain fenomenologi. Infoman dalam penelitian ini terdiri dari 3 informan utama dan 4 informan triangulasi yang ditentukan dengan teknik purposive sampling. Teknik pengambilan data berupa wawancara mendalam. Analisis data dilakukan secara deskriptif dan disajikan dalam bentuk narasi. Hasil penelitian menunjukkan tenaga (man) surveilans DBD belum sesuai pedoman. Sarana dan prasarana (material-machine) yang meliputi ketersediaan perangkat komputer/laptop, dan ketersediaan perangkat surveilans lain belum sesuai pedoman. Sedangkan sarana dan prasarana (materialmachine) yang meliputi ketersediaan formulir surveilans DBD, ketersediaan alat tulis kantor, dan ketersediaan alat komunikasi sudah sesuai pedoman. Sasaran (market) informasi hasil surveilans sudah sesuai pedoman. Kebutuhan informasi hasil surveilans DBD sesuai dengan kebutuhan pengguna informasi. Pendanaan (money) surveilans DBD sudah sesuai pedoman. Metode (method) surveilans DBD yang terdiri dari ketersediaan pedoman evaluasi surveilans DBD dan ketersediaan SOP surveilans DBD sudah sesuai pedoman. Saran yang peneliti rekomendasikan adalah meningkatkan kemampuan dan jumlah tenaga surveilans DBD, dan meningkatkan jumlah sarana dan prasarana penunjang kegiatan surveilans DBD di Dinas Kesehatan Kab. Tegal.

Abstract
\end{abstract}

DHF (Dengue Haemorrhagic Fever) surveillance is one of the activities in the prevention and control of dengue cases. Purpose of the research was to determine the input of Dengue Haemorrhagic Fever surveillance system in Tegal District Health Office. The research was a descriptive one with a qualitative approach and phenomenology design. Informants in this research consist of 3 main informants and 4 triangulation informants determined by purposive sampling technique. Data collection technique was in shape of deep interviews. Data analysis was done descriptively and presented in narrative form. The results showed that power resource (men) of DHF surveillance was not appropriate yet with guidelines. Facilities and infrastructure (materialmachine) that includes the availability of a computer / laptop, and the availability of other surveillance device were not appropriate with guidelines. While the facilities and infrastructure (material-machine) which includes the availability of dengue surveillance forms, availability ATK (office stationery), and the availability of means of communication was appropriate with guidelines. Information Target (market) of the surveillance results is appropriate with guidelines. Information need of DHF surveillance results was in accordance with the needs of information users. Funding (money) of DHF surveillance is appropriate with guidelines. Method of dengue surveillance which consists of the availability of DHF surveillance guidelines and the availability of DHF surveillance SOP is appropriate with the guidelines. Suggestions that the researcher recommends is to increase the skill and the number of dengue surveillance personnel, and to increase the number of supporting infrastructures of dengue surveillance activities in Tegal District Health Office.

(C) 2016 Universitas Negeri Semarang

\footnotetext{
Alamat korespondensi:

Gedung F1 Lantai 2 FIK Unnes

Kampus Sekaran, Gunungpati, Semarang, 50229

E-mail: mufidz.maulana325@gmail.com
} 


\section{PENDAHULUAN}

Data DBD dari seluruh dunia menunjukkan Asia menempati urutan pertama dalam jumlah penderita DBD setiap tahunnya (Natalia, S, 2012). Sementara itu, terhitung sejak tahun 1968 hingga tahun 2009, WHO mencatat Indonesia sebagai negara dengan kasus DBD tertinggi di Asia Tenggara (Pusat Data dan Surveilans Epidemiologi Kemenkes RI, 2010).

Penyakit DBD mulai dikenal di Indonesia sejak tahun 1968 di Surabaya dan Jakarta, dan setelah itu jumlah kasus DBD terus bertambah seiring dengan meluasnya daerah endemis DBD (Lasut, D, 2009; Chadijah, S, 2011). Penyakit ini sering menimbulkan KLB 3 di beberapa daerah endemis (Widiarti, dkk, 2009; Sukowinarsih, ET, 2010). Kasus DBD terbanyak dilaporkan di daerah yang tingkat kepadatan penduduknya tinggi seperti provinsi di Jawa, Bali dan Sumatera. Jumlah kasus DBD yang dilaporkan pada tahun 2012 sebanyak 90.245 kasus dengan jumlah kematian 816 orang (IR/Angka kesakitan $=37,11$ per 100.000 penduduk dan $\mathrm{CFR}=0,90 \%$ ). Tahun 2011 Propinsi Jawa Tengah menempati peringkat kedua tertinggi di Indonesia dengan jumlah 2.345 kasus. Pada tahun 2012 jumlah kasus Demam Berdarah Jawa Tengah 7.088 kasus dan 108 kematian $(\mathrm{CFR}=1,5 \%)$ (Ditjen PP dan PL Kemenkes RI, 2013).

Dari 35 kabupaten/kota di Jawa Tengah sudah pernah terjangkit penyakit

Demam Berdarah Dengue. Angka kesakitan/IR DBD di Provinsi Jawa Tengah pada tahun 2012 sebesar 19,29/100.000 penduduk, meningkat bila dibandingkan tahun $2011(15,27 / 100.000$ penduduk). Angka kematian/CFR DBD di

Jawa Tengah tahun 2012 sebesar 1,5\% lebih tinggi dibanding tahun 2011 $(0.93 \%)$, dan masih lebih tinggi dibandingkan dengan target nasional $(<1 \%$ ) (Dinas Kesehatan Provinsi Jawa Tengah, 2014).

Pada tahun 2012 kota/kab di Jawa Tengah dengan CFR DBD tertinggi adalah Kab. Wonogiri dengan CFR sebesar 23,08\% diikuti Kab. Tegal dengan CFR sebesar 4,5\%. Pada tahun 2012 di Kab.

Tegal ditemukan kasus DBD sebesar 202 kasus, dan 8 penderita di antaranya meninggal dunia (CFR $=3,96 \%)$, sehingga belum memenuhi target Indonesia Sehat 2011 (CFR kurang dari 1\%) (Dinas Kesehatan Kab. Tegal 2012). Sedangkan pada tahun 2013 kasus Deman Berdarah Dengue (DBD) di Kab. Tegal sebanyak 243 kasus, dan 11 penderita diantaranya meninggal dunia $(\mathrm{CFR}=$ 4,5\%), sehingga belum memenuhi target Indonesia Sehat 2011 (CFR kurang dari 1\% ) (Dinas Kesehatan Kab. Tegal, 2013).

Untuk itu, perlu diadakan kegiatan surveilans epidemiologi. Surveilans epidemiologi merupakan suatu kegiatan yang sangat penting dalam mendukung pengendalian dan penanggulangan penyakit menular, tidak terkecuali pada kegiatan pengendalian dan penanggulangan penyakit DBD (Wuryanto, MA, 2008).

Berdasarkan studi pendahuluan yang telah dilakukan peneliti, masalah surveilans Demam Berdarah Dengue (DBD) di Dinas Kesehatan Kab. Tegal adalah ketepatan waktu dan kelengkapan Laporan Puskesmas (DP-DBD, K-DBD, PJB-R) yang diterima Dinas Kesehatan Kabupaten Tegal belum mencapai indikator kinerja baik dari Depkes tahun 2011 yaitu 80\%. Persentase ketepatan waktu laporan (DP- 
DBD, K-DBD, PJB-R) yang diterima Dinas Kesehatan Kabupaten Tegal dari bulan Januari sampai Desember tahun 2013 sebesar $60 \%$ sehingga memiliki selisih $40 \%$ dari target Dinas Kesehatan Kab. Tegal dan $20 \%$ dari indikator kinerja baik dari Depkes. Persentase kelengkapan laporan Data Dasar Personal DBD pada tahun 2013 sebesar $72 \%$ sehingga belum mencapai indikator kinerja baik dari Depkes sebesar $80 \%$.

Pada input, ketersediaan tenaga surveilans di Dinas Kesehatan Kabupaten Tegal sudah ada, ketersediaan data sudah ada yaitu Laporan KD-DBD/KD-RS dari rumah sakit, Laporan Mingguan dari puskesmas, serta laporan hasil surveilans aktif oleh DKK. Sarana surveilans yang tersedia di Dinas Kesehatan Kab. Tegal adalah form laporan untuk puskesmas KDRS, SMS EWARS dan form laporan yang belum tersedia adalah K-DBD dan form DP-DBD. Dana surveilans sudah cukup untuk keperluan operasional surveilans.

Berdasarkan uraian latar belakang di atas, terdapat masalah surveilans DBD di Dinas Kesehatan Kabupaten Tegal antara lain CFR DBD di Kabupaten Tegal belum mencapai target $<1 \%$, persentase ketepatan waktu laporan (DP-DBD, K-DBD, PJB-R) yang diterima Dinas Kesehatan Kabupaten Tegal belum mencapai target Dinas Kesehatan Kabupaten Tegal dan persentase kelengkapan DP-DBD pada tahun 2013 sebesar $72 \%$ sehingga belum mencapai indikator kinerja baik dari Depkes sebesar $80 \%$, masalah kompetensi sumber daya manusia dan sarana prasarana yang rendah. Hal ini didukung dengan penelitian sebelumnya oleh Laras (2010) bahwa terdapat masalah surveilans berupa kualitas SDM dan sarana prasarana masih rendah. Kemudian penelitian yang dilakukan oleh
Sulistya (2006) bahwa terdapat masalah kualitas SDM yang rendah.

Tujuan penelitian ini adalah untuk mengevaluasi input sistem surveilans DBD di Dinas Kesehatan Kab. Tegal.

\section{METODE}

Jenis penelitian ini adalah deskriptif kualitatif dengan rancangan penelitian studi evaluasi. Pemilihan desain studi kualitatif dikarenakan hasil penelitian tidak untuk digeneralisasikan data yang akan dihasilkan hanya berupa data kuantitatif dan data kualitatif. Selain itu, dengan penelitian kualitatif, peneliti dapat ikut berpartisipasi di tempat penelitian, mencatat dan melakukan analisis mengenai sistem surveilans Demam Berdarah Dengue di Dinas Kesehatan Tegal tahun 2013 secara mendetail (Sugiyono, 2008). Studi evaluasi dilakukan untuk menilai pelaksanaan maupun capaian dari kegiatan atau program yang sedang atau yang sudah dilakukan untuk meningkatkan dan memperbaiki kegiatan atau program tersebut (Notoadmodjo, 2010).

Teknik pengambilan informan secara purposive sampling. Kriteria yang ditentukan peneliti untuk informan yaitu pegawai Bidang P2P DKK Tegal tahun 2014, petugas yang terlibat langsung pada teknis dan pengambilan keputusan program P2DBD di DKK Tegal tahun 2014. Informan utama penelitian ini yaitu Kabid P2P, Kasie P2 dan Pengelola Program P2DBD di DKK Tegal tahun 2014. Informan triangulasi yaitu 2 staf Subbagian Perencanaan dan Keuangan, Kasubbag Umum, dan Kasubbag Kepegawaian DKK Tegal tahun 2014. Pengambilan data dilakukan dengan cara wawancara terstruktur dan studi dokumentasi. Alat bantu yang digunakan dalam pengumpulan 
data adalah panduan wawancara terstruktur, alat perekam dan lembar observasi. Uji keabsahan data dilakukan dengan teknik triangulasi sumber, yaitu dengan cara membandingkan hasil wawancara antara informan utama dan informan triangulasi.

Teknik analisis data dalam penelitian ini menggunakan teknik analisis data model Miles dan Huberman. Analisis dimulai dari pengumpulan data, reduksi data, penyajian data, evaluasi data dan penarikan kesimpulan (Sugiyono, 2008).

\section{HASIL DAN PEMBAHASAN}

Penelitian dilakukan terhadap 7 informan yang bertugas di Dinas Kesehatan Kab. Tegal yang terdiri dari 3 informan utama dan 4 informan triangulasi. Berdasarkan hasil wawancara terstruktrur terhadap masing-masing informan diperoleh hasil penelitian sebagai berikut:

\section{Karakteristik Informan}

Informan utama $(100 \%)$ berjenis kelamin perempuan. $33 \% \quad(1$ orang) informan berada dalam kelompok usia 3039 tahun. 67\% (2 orang) informan berada dalam kelompok usia 40-49 tahun. Untuk pendidikan terakhir, 1 orang informan S1 Dokter Umum keperawatan, 1 orang S2 Manajemen Kesehatan dan 1 orang S1 Kesehatan Masyarakat. Sedangkan untuk lama bertugas informan, 1 orang informan telah bertugas selama 1 tahun, 1 orang bertugas selama 2 tahun dan 1 orang bertugas selama 7 bulan.

\section{Evaluasi Input Sumber Daya Manusia (Man) Surveilans DBD di DKK Tegal}

Tabel 1. Perbandingan antara Input Man Kenyataan di Tempat Penelitian dan Tataran Ideal

\begin{tabular}{llll}
\hline Kriteria & Pedoman/Diskripsi & Kenyataan & Kesesuaian \\
\hline Jumlah tenaga & Tenaga Surveilans Epidemiologi di & Tenaga surveilans DBD di Belum sesuai \\
surveilans & tingkat Dinas Kesehatan Kab./ DKK Tegal berjumlah 2 & DKa \\
DBD & Kota terdiri dari: 1 tenaga & orang yang berlatarbelakang \\
& epidemiologi ahli (S2), 2 tenaga & pendidikan S1 Kesehatan \\
& epidemiologi ahli (S1) atau terampil & Masyarakat (Epidemiologi) \\
& dan 1 tenaga dokter umum. & dan 1orang lainnya \\
& & berlatarbelakang pendidikan \\
& & S2 Manajemen Kesehatan.
\end{tabular}

\begin{tabular}{llrrrr}
\hline Ketersediaan & Pelatihan & adalah & proses & Tidak ada & tenaga yang Belum sesuai \\
Tenaga & pembelajaran & dalam & rangka & mendapatkan & pelatihan \\
Terlatih dalam & meningkatkan & & kinerja, & manajemen & pengendalian \\
Manajemen & profesionalisme & dan & atau & DBD. Masalah ini diperkuat \\
Program dan & menunjang & pengembangan & karier & lagi dengan & tidak \\
Teknis P2DBD & tenaga & kesehatan & dalam & ditemukannya & sertifikat \\
& melaksanakan tugas dan fungsinya. & pelatihan & manajemen \\
& & & & pengendalian DBD. \\
\hline
\end{tabular}


Berdasarkan Tabel 1 dapat dilihat bahwa jumlah tenaga surveilans DBD di DKK Tegal belum sesuai pedoman. Hal itu sesuai dengan penelitian yang dilakukan Siyam (2010) bahwa jumlah tenaga untuk surveilans belum memadai, padahal faktor tenaga juga mempengaruhi keberhasilan pelaksanaan pelaporan surveilans DBD. Hal senada juga disampaikan oleh Rahayu (2012) bahwa untuk dapat menjalankan

pelayanan kesehatan yang bermutu dibutuhkan jenis, jumlah dan kualifikasi dari tenaga kesehatan. Jumlah tenaga yang tidak memadai menyebabkan pelaksanaaan kegiatan program $\mathrm{P} 2 \mathrm{DBD}$ tidak dapat dilaksanakan dengan baik. Pendidikan akan mempengaruhi terbentuknya perilaku secara tidak langsung, karena

semakin tinggi tingkat pendidikan seseorang akan mempengaruhi tingkat pengetahuannya dan tingkat pengetahuan merupakan salah satu domain dalam pembentukkan perilaku (Natalia, A, 2012). Pembagian tugas di program P2DBD, 1 orang bertugas sebagai pemegang program dan pelaksana program P2DBD dan 1 orang lainnya bertugas sebagai pemegang anggaran $\mathrm{P} 2 \mathrm{DBD}$ dalam manajemen program P2DBD. Di samping itu, 1 orang tenaga surveilans DBD juga merangkap sebagai pemegang program penyakit lain dan 1 orang tenaga lainnya merangkap sebagai kepala seksi pemberantasan penyakit di Dinas Kesehatan Kab. Tegal. Hal ini sesuai dengan penelitian yang dilakukan oleh Frans (2010) bahwa petugas mengerjakan tugas rangkap, hal ini membuat kegiatan surveilans tidak sesuai dengan semestinya dan menyebabkan waktu mereka menjadi terbagi sehingga menyebabkan pelaksanaan semua komponen dari sistem surveilans mejadi kurang optimal.
Berdasarkan Tabel 1 dapat dilihat bahwa ketersediaan tenaga terlatih dalam Manajemen dan Teknis P2DBD yang dibandingkan dengan tataran ideal, belum sesuai. Tetapi untuk mengatasi permasalahan kurangnya pengetahuan dan keterampilan mengenai pengendalian DBD, pihak Dinas Kesehatan Kab. Tegal menugaskan petugas P2DBD untuk mengikuti rapat-rapat koordinasi, seminar, maupun workshop program-program baru pengendalian $\mathrm{DBD}$.

\section{Evaluasi Input Sarana-prasarana (Material- machine) Surveilans DBD di DKK Tegal \\ Evaluasi terhadap input sarana dan} prasarana (material-machine) dalam pelaksanaan surveilans DBD di Dinas Kesehatan Kab. Tegal meliputi: evaluasi terhadap ketersediaan formulir surveilans DBD, evaluasi terhadap ketersediaan alat tulis kantor (ATK), evaluasi terhadap ketersediaan perangkat komputer/laptop, evaluasi terhadap ketersediaan alat komunikasi, dan evaluasi terhadap perangkat surveilans lain.

Formulir surveilans DBD merupakan instrumen penting dalam pelaporan DBD. Tidak ditemukan formulir W1 di program P2DBD karena yang mencetak dan menggunakan form W1 adalah tim surveilans umum dan khusus dari seksi Imunisasi. Jumlah formulir yang tersedia dan yang digunakan sudah mencukupi. Berdasarkan Tabel 2 dapat disimpulkan bahwa ketersediaan formulir surveilans DBD di Dinas Kesehatan Kab. Tegal sudah sesuai dengan tataran ideal.

Tabel 2. Perbandingan antara Input Material-machines di Tempat Penelitian dan Tataran Ideal 
Maulana Mufidz / Unnes Journal of Public Health 5 (2) (2016)

\begin{tabular}{|c|c|c|c|}
\hline Kriteria & Pedoman/Diskripsi & Kenyataan & Kesesuaian \\
\hline $\begin{array}{l}\text { Ketersediaan } \\
\text { formulir } \\
\text { surveilans DBD }\end{array}$ & $\begin{array}{l}\text { Menurut Ditjen PP dan PL } \\
\text { Kemenkes RI tahun 2011, } \\
\text { formulir pelaporan surveilans } \\
\text { DBD di Dinas Kesehatan } \\
\text { Kab./Kota terdiri dari DP-DBD, } \\
\text { form KDRS, form K-DBD, form } \\
\text { W1 dan form W2. Jumlah } \\
\text { formulir disesuaikan dengan } \\
\text { kebutuhan setiap kondisi. }\end{array}$ & $\begin{array}{l}\text { Formulir yang tersedia dan } \\
\text { digunakan oleh petugas } \\
\text { pemegang program P2DBD } \\
\text { dalam melaksanakan } \\
\text { surveilans DBD terdiri dari: } \\
\text { form DP-DBD, KDRS, dan } \\
\text { K-DBD serta W2. Formulir } \\
\text { PSN dan PE sebagai } \\
\text { tambahan. }\end{array}$ & Sudah sesuai \\
\hline
\end{tabular}

\begin{tabular}{|c|c|c|}
\hline $\begin{array}{l}\text { Keters } \\
\text { ATK }\end{array}$ & $\begin{array}{l}\text { Menurut Ditjen PPM dan PL } \\
(2003) \text { bahwa yang termasuk } \\
\text { ATK pada surveilans DBD } \\
\text { sekurang-kurangnya meliputi: } \\
\text { pensil, bolpoin, penggaris, kertas } \\
\text { hvs, stempel beserta tinta dan } \\
\text { penjepit kertas. }\end{array}$ & $\begin{array}{l}\text { Alat tulis kantor yang Sudah sest } \\
\text { digunakan terdiri dari } \\
\text { bolpoin, pensil, penggaris, } \\
\text { kertas hvs/prin, stempel } \\
\text { beserta tinta dan penjepit } \\
\text { kertas. } \\
\text { Jumlah ATK mencukupi } \\
\text { dan dalam kondisi baik. }\end{array}$ \\
\hline $\begin{array}{l}\text { Ketersediaan } \\
\text { Perangkat } \\
\text { Komputer/ laptop }\end{array}$ & $\begin{array}{l}\text { Menurut Ditjen PPM dan PL } \\
\text { (2003), perangkat komputer } \\
\text { untuk program surveilans terdiri } \\
\text { dari: perangkat } \\
\text { komputer/laptop, printer, kertas } \\
\text { HVS, program Ms. Office dan Epi } \\
\text { map/ Epi info. }\end{array}$ & $\begin{array}{l}\text { Perangkat komputer yang } \text { Belum sesuai } \\
\text { digunakan terdiri dari } 1 \\
\text { seperangkat komputer, } 1 \\
\text { unit laptop, kertas Hvs, } 1 \\
\text { unit printer, program Ms. } \\
\text { office di komputer dan } \\
\text { laptop dan } 2 \text { flasdisk. }\end{array}$ \\
\hline $\begin{array}{l}\text { Ketersediaan Alat } \\
\text { Komunikasi }\end{array}$ & $\begin{array}{l}\text { Menurut KMK RI No. 1116/ } \\
\text { Menkes/SK/VIII/2003, salah } \\
\text { satu sarana yang harus ada pada } \\
\text { sistem surveilans epidemiologi } \\
\text { kesehatan di tingkat dinas } \\
\text { kesehatan kabupaten adalah } 1 \\
\text { paket alat komunikasi yang } \\
\text { meliputi: telepon, faksimil, SSB, } \\
\text { dan telekomunikasi lainnya. }\end{array}$ & $\begin{array}{l}\text { Jenis alat komunikasi yang } \text { Sudah sesuai } \\
\text { digunakan terdiri dari } \\
\text { telepon, HP, faksimil, } \\
\text { jaringan internet, SMS } \\
\text { gateway. } \\
3 \text { alat komunikasi dalam } \\
\text { kondisi baik berjumlah } 3 \\
\text { dan } 2 \text { dalam kondisi rusak }\end{array}$ \\
\hline $\begin{array}{l}\text { Ketersediaan } \\
\text { Perangkat } \\
\text { Surveilans Lain }\end{array}$ & $\begin{array}{l}\text { Menurut Ditjen PPM dan PL } \\
\text { (2003) perangkat surveilans lain } \\
\text { terdiri dari: kalkulator dan kertas } \\
\text { grafik. }\end{array}$ & $\begin{array}{ll}\text { Perangkat surveilans } & \text { lain } \\
\text { yang tersedia } & \text { adalah sesuai } \\
\text { kalkulator dalam } & \text { jumlah } \\
\text { yang mencukupi. } & \end{array}$ \\
\hline
\end{tabular}

Ketersediaan Perangkat Surveilans Lain Menurut Ditjen PPM dan PL (2003) perangkat surveilans lain terdiri dari: kalkulator dan kertas grafik. Perangkat surveilans lain yang tersedia adalah kalkulator dalam jumlah yang mencukupi. Belum sesuai

ATK (Alat tulis kantor) adalah peralatan habis pakai yang digunakan untuk membantu pelaksanaan kegiatan rutin di program $\mathrm{P} 2 \mathrm{DBD}$. Berdasarkan 
Tabel 2 diketahui bahwa ketersediaan ATK di program $\mathrm{P} 2 \mathrm{DBD}$ sudah sesuai dengan tataran ideal.

Untuk menunjang pelaksanaan surveilans DBD dalam hal pengolahan data dibutuhkan perangkat komputer/laptop sehingga akan dihasilkan keluaran yang dapat dibaca, dipahami dan digunakan oleh petugas surveilans DBD. Pengadaan perangkat komputer yang digunakan dalam pelaksanaan surveilans DBD berasal dari Subbagian Umum Dinas Kesehatan Kab. Tegal. Perangkat komputer yang ada digunakan bergantian dengan program penyakit lain. Untuk mengatasi keterbatasan perangkat komputer pada pengelolaan program P2DBD maka digunakan laptop dari program penyakit lain. Berdasarkan ketersediaan perangkat komputer/laptop pada Tabel 2 dapat disimpulkan bahwa perangkat komputer yang digunakan oleh pemegang program P2DBD Dinas Kesehatan Kab. Tegal belum sesuai. Hal itu dikarenakan perangkat komputer belum memiliki perangkat lunak Epi Info dan Epi Maps. Ditambah dengan laptop yang rusak.

Alat komunikasi digunakan pada saat pelaporan atau penyebaran informasi hasil surveilans DBD antar bidang maupun instansi. Pengadaan alat komunikasi dilakukan oleh Subbagian Umum kecuali HP yang pengadaannya secara pribadi. Berdasarkan Tabel 2, dapat disimpulkan bahwa ketersediaan alat komunikasi di tempat penelitian sudah sesuai.
Perangkat surveilans lain adalah perangkat surveilans diluar perangkat surveilans seperti alat komunikasi, dan perangkat komputer. Walaupun hanya

bersifat sebagai pendukung, tetapi perangkat surveilans lain juga memegang peranan penting dalam kelancaran pelaksanaan surveilans DBD. Berdasarkan Tabel 2 ketersediaan perangkat surveilans lain belum sesuai dengan tataran ideal.

\section{Evaluasi Input Sasaran (Market) Surveilans DBD di DKK Tegal}

Evaluasi terhadap sasaran informasi dalam pelaksanaan surveilans DBD di Dinas Kesehatan Kab. Tegal meliputi: evaluasi pengguna informasi dan evaluasi informasi hasil surveilans DBD.

Salah satu komponen dari surveilans epidemiologi adalah penyebarluasan informasi (Ditjen PPM dan PL, 2003). Berdasarkan Tabel 3, pengguna informasi hasil surveilans DBD di tempat penelitian sudah sesuai dengan tataran ideal.

Informasi hasil surveilans yang diberikan harus disesuaikan dengan

pengguna informasi surveilans. Berdasarkan Tabel 3, kebutuhan informasi hasil surveilans yang didistribusikan oleh pemegang program P2DBD seksi Pemberantasan sudah sesuai dengan tataran ideal.

Tabel 3. Perbandingan antara Input Market di Tempat Penelitian dan Tataran Ideal

\begin{tabular}{llll}
\hline Kriteria & Pedoman/Diskripsi & Kenyataan & Kesesuaian \\
\hline
\end{tabular}




\begin{tabular}{|c|c|c|}
\hline $\begin{array}{l}\text { Pengguna } \\
\text { Informasi } \\
\text { Hasil } \\
\text { Surveilans } \\
\text { DBD }\end{array}$ & $\begin{array}{l}\text { Menurut Ditjen PPM dan PL } \\
\text { (2003), salah satu kegiatan dalam } \\
\text { surveilans epidemiologi adalah } \\
\text { instansi surveilans epidemiologi } \\
\text { memiliki sasaran dalam kegiatan } \\
\text { penyebarluasan informasi hasil } \\
\text { pelaksanaan surveilans. }\end{array}$ & $\begin{array}{lr}\text { Pengguna } & \text { informasi } \\
\text { internal meliputi: } & \text { Subbag } \\
\text { Perencanaan } & \text { dan } \\
\text { Keuangan, } & \text { Bidang } \\
\text { Promkes dan } & \text { Penyehatan } \\
\text { Lingkungan dan UPTD } \\
\text { DKK Tegal. Sedangkan } \\
\text { pengguna } & \text { informasi } \\
\text { eksternal r meliputi: } \\
\text { BAPPEDA Kab. Tegal, } \\
\text { Komisi IV DPRD Kab. } \\
\text { Tegal, Dinkes Provinsi } \\
\text { Jateng, dan Wartawan. }\end{array}$ \\
\hline $\begin{array}{l}\text { Kebutuhan } \\
\text { Informasi } \\
\text { Hasil } \\
\text { Surveilans } \\
\text { DBD }\end{array}$ & $\begin{array}{l}\text { Menurut Ditjen PP dan PL } \\
\text { Kemenkes (2011), informasi yang } \\
\text { didistribusikan ke sasaran } \\
\text { informasi surveilans } \\
\text { minimal DBD } \\
\text { endemisitas dan distribusi } \\
\text { DBD per kecamatan } \\
\text { grafik dan mapping)dan data } \\
\text { kecenderungan penyakit DBD. }\end{array}$ & $\begin{array}{l}\text { Data yang dibutuhkan oleh } \\
\text { pengguna data/informasi } \\
\text { hasil surveilans DBD baik } \\
\text { di Dinas Kesehatan Kab. } \\
\text { Tegal maupun } \\
\text { lembaga/instansi di luar } \\
\text { Dinas Kesehatan Kab. } \\
\text { Tegal meliputi data jumlah } \\
\text { kasus DBD dan wilayah } \\
\text { terkena DBD. }\end{array}$ \\
\hline
\end{tabular}

Evaluasi Input Pendanaan (Money) Surveilans DBD di DKK Tegal

Pendanaan atau biaya merupakan komponen penting dari sebuah organisasi. Tanpa adanya pendanaan, organisasi tidak bisa menjalankan program-program yang sudah direncanakan.

Tabel 4. Perbandingan antara Input Money di tempat penelitian dan tataran ideal

\begin{tabular}{|c|c|c|c|}
\hline Kriteria & Pedoman/Diskripsi & Kenyataan & Kesesuaian \\
\hline $\begin{array}{l}\text { Pendanaan } \\
\text { Program } \\
\text { surveilans } \\
\text { DBD }\end{array}$ & 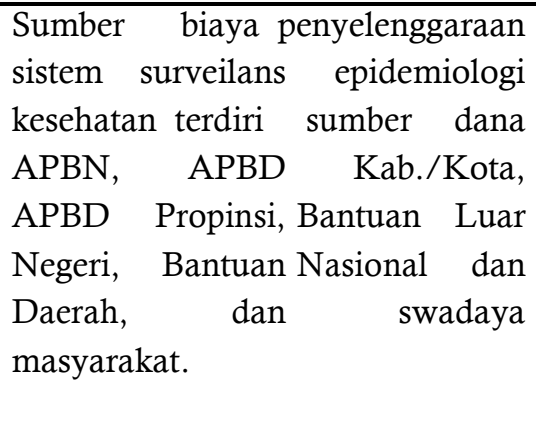 & 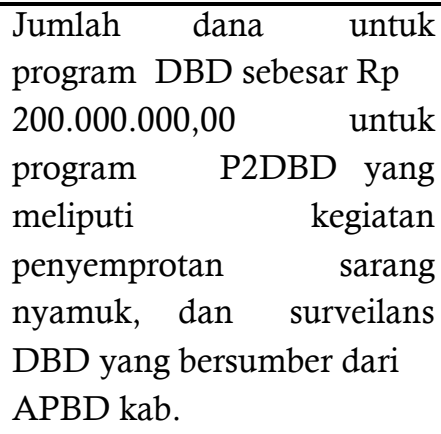 & Sudah sesuai \\
\hline
\end{tabular}

Jumlah tersebut dapat berubah-ubah setiap waktu sesuai perubahan kondisi program setiap tahunnya. Jumlah tersebut sudah mencukupi untuk surveilans DBD. Hal itu sejalan dengan hasil penelitian yang dilakukan oleh Frans (2010) bahwa dana APBD kabupaten yang dialokasikan dari tahun ke tahun fluktuatif, dana tersebut juga lebih banyak diprioritaskan kepada hal-hal teknis berupa alat operasional tetapi 
kurang kepada pengembangan kemampuan petugas berupa pelatihanpelatihan. Hal senada juga disampaikan oleh Rahayu (2012) bahwa jika belum tersedianya dana yang cukup dapat menyebabkan tidak maksimalnya pelaksanaan kegiatan. Berdasarkan Tabel 4, pendanaan surveilans DBD sudah sesuai dengan tataran ideal.

\section{Evaluasi Input Metode (Method) Surveilans DBD di DKK Tegal}

Evaluasi metode dalam pelaksanaan surveilans DBD meliputi evaluasi terhadap ketersediaan pedoman evaluasi surveilans DBD dan evaluasi terhadap ketersediaan SOP surveilans DBD.

Tabel 4. Perbandingan antara Input Money di tempat penelitian dan tataran ideal

\begin{tabular}{|c|c|c|c|}
\hline Kriteria & Pedoman/Diskripsi & Kenyataan & Kesesuaian \\
\hline $\begin{array}{l}\text { Ketersediaan } \\
\text { Pedoman } \\
\text { Evaluasi } \\
\text { Surveilans } \\
\text { DBD }\end{array}$ & $\begin{array}{l}\text { Pedoman dalam evaluasi } \\
\text { surveilans dibagi dalam } 2 \text { bentuk } \\
\text { yaitu dalam bentuk pedoman dan } \\
\text { peraturan. }\end{array}$ & $\begin{array}{lr}\begin{array}{l}\text { Pedoman yang digunakan } \\
\text { adalah }\end{array} & \text { Modul } \\
\text { Pengendalian DBD } & \text { tahun } \\
2011 . \quad \text { Evaluasi } & \text { juga } \\
\text { dilakukan malalui rapat- } & \text { rapat koordinasi }\end{array}$ & Sudah sesuai \\
\hline $\begin{array}{l}\text { Ketersediaan } \\
\text { SOP } \\
\text { Surveilans } \\
\text { DBD }\end{array}$ & $\begin{array}{ll}\text { Pedoman yang bersifat } & \text { teknis } \\
\text { di lapangan diwujudkan dalam } \\
\text { bentuk SOP yang disusun } \\
\text { berdasarkan peraturan dan } \\
\text { pedoman. }\end{array}$ & $\begin{array}{l}\text { SOP yang digunakan } \\
\text { terdiri dari: Modul } \\
\text { Pengendalian DBD tahun } \\
2011 \text { dan SPO Program } \\
\text { P2DBD No. kode } 440 \\
\text { terbitan 2014 oleh Dinas } \\
\text { Kesehatan Kab. Tegal }\end{array}$ & Sudah sesuai \\
\hline
\end{tabular}

Evaluasi program kesehatan merupakan serangkaian prosedur untuk menilai suatu program kesehatan dan memperoleh informasi tentang keberhasilan pencapaian tujuan. SOP adalah suatu pernyataan tertulis yang disusun secara sistematis dan dapat dipakai sebagai pedoman oleh para pelaksana dalam pengambilan keputusan. SOP dapat dipakai sebagai pedoman oleh para pelaksana dalam pengambilan keputusan (Rahayu, 2012). Berdasarkan Tabel 4, pedoman evaluasi surveilans DBD dan ketersediaan SOP surveilans DBD sudah sesuai dengan tataran ideal.

\section{SIMPULAN}

Berdasarkan hasil penelitian mengenai evaluasi input sistem surveilans
Demam Berdarah Dengue di Dinas Kesehatan Kab. Tegal, dapat disimpulkan bahwa: Tenaga (man) surveilans DBD program P2DBD Dinas Kesehatan Kab. Tegal belum sesuai dengan tataran ideal. Sarana dan prasarana (material-machine) pelaksanaan surveilans DBD program P2DBD Dinas Kesehatan Kab. Tegal yang sudah sesuai dengan pedoman adalah ketersediaan formulir surveilans DBD, ketersediaan ATK, ketersediaan alat komunikasi. Sedangkan sarana dan prasarana yang belum sesuai dengan pedoman meliputi ketersediaan perangkat komputer/laptop, dan ketersediaan perangkat lain. Sasaran (market) informasi dalam pelaksanaan surveilans DBD sudah sesuai pedoman karena informasi hasil surveilans DBD sudah memiliki dan 
menyebarluaskannya

sasaran/pengguna informasi hasil surveilans DBD. Demikian pula dengan kebutuhan informasi hasil surveilans DBD yang sudah memberikan informasi sesuai dengan kebutuhan pengguna informasi hasil surveilans DBD. Pendanaan (money) dalam pelaksanaan surveilans DBD di Dinas Kesehatan Kab. Tegal sudah sesuai dengan tataran ideal. Metode (method) dalam pelaksanaan surveilans DBD di Dinas Kesehatan Kab. Tegal yang terdiri dari ketersediaan pedoman evaluasi surveilans DBD dan ketersediaan SOP surveilans DBD sudah sesuai.

\section{UCAPAN TERIMA KASIH}

Ucapan terima kasih kami tunjukkan kepada Dekan Fakultas Ilmu Keolahragaan, Ketua Jurusan Ilmu

Kesehatan Masyarakat, Dosen Pembimbing, Kepala Dinas Kesehatan Kab. Tegal, dan Informan yang terlibat dalam penelitian ini.

\section{DAFTAR PUSTAKA}

Chadijah, S, dkk. 2011. Peningkatan Peranserta Masyarakat dalam Pelaksanaan Pemberantasan Sarang Nyamuk DBD (PSNDBD) di Dua Kelurahan di Kota Palu Sulawesi Tengah, Media Litbang Kesehatan, Vol. 21, No. 4 Tahun 2011, Hal. 183-190.

Dinas Kesehatan Kab. Tegal, 2013, Profil Kesehatan Kab. Tegal 2012, Dinas Kesehatan Kab. Tegal, Tegal.

Dinas Kesehatan Jawa Tengah, 2014, Buku Saku Kesehatan Triwulan 3 Tahun 2013, Dinas Kesehatan Provinsi Jawa Tengah, Semarang.

Ditjen PPM dan PL Depkes RI, 2003, Surveilans Epidemiologi Penyakit (PEP) Edisi 1, Depkes RI, Jakarta.
Ditjen PP dan PL Kemenkes RI, 2011, Modul Pengendalian Demam Berdarah Dengue, Kemenkes RI, Jakarta.

Ditjen PP dan PL Kemenkes RI, 2013, Profil Pengendalian dan Penyehatan Lingkungan tahun 2012, Kemenkes RI, Jakarta.

Frans, YS, Antonius S, Dibyo, P, 2010, Evaluasi dan Implementasi Sistem Surveilans Demam Berdarah Dengue (DBD) di Kota Singkawang-Kalimantan Barat tahun 2010, BALABA, Vol. 8, No. 1, Tahun 2011, Hal. 510.

Laras, P, 2010, Evaluasi Sistem Surveilans DBD Berdasarkan Komponen dan Atribut Surveilans di DKK Trenggalek, Thesis, Unair, Surabaya.

Lasut, D, dkk, 2009, Karakteristik Dan Pergerakan Sebaran Penderita DBD Berdasarkan Geographic Information System Sebagai Bagian Sistem Informasi Surveilans di Kecamatan Karawang Barat Kabupaten Karawang Provinsi Jawa Barat, Aspirator, Vol. 1, No. 1, Tahun 2009, Hal. 41-45.

Natalia, A, 2012, Gambaran Pelaksanaan Surveilans Epidemiologi Penyakit Demam Berdarah Dengue Ditinjau Dari Aspek Petugas Di Tingkat Puskesmas Kota Semarang Tahun 2011, Jurnal Kesehatan Masyarakat, Vol. 1, No. 2, Tahun 2012, Hal. 262 - 271.

Notoatmodjo, S, 2010, Metodologi Penelitian Kesehatan, Rineka Cipta, Jakarta.

Pusat Data dan Surveilans Epidemiologi Kemenkes RI, 2010, Buletin Jendela Epidemiologi: Demam Berdarah Dengue, Kemenkes RI, Jakarta.

Rahayu, T, 2012, Evaluasi Pelaksanaan Program Pencegahan dan Penanggulangan Penyakit Demam Berdarah Dengue di Wilayah Kerja Puskesmas Ketapang 2 (Studi di Kecamatan Mentawa Baru Ketapang Kabupaten Kotawaringin Timur Propinsi Kalimantan Tengah), Jurnal Kesehatan Masyarakat, Vol. 1, No. 2, Tahun 2012, Hal. 479 - 492. 
Siyam, N, 2010, Fasilitasi Pelaporan KD-RS dan W2 DBD Untuk Meningkatkan Pelaporan Surveilans DBD. KEMAS, Vol. 8, No. 2, Tahun 2013, Hal. 113-120.

Sugiyono, 2008, Metode Penelitian Kuantitatif, Kualitatif dan R\&D, Penerbit AlfaBeta, Bandung.

Sulistya, 2006, Evaluasi Kegiatan Pelaksanaan Surveilans Malaria Di Dinas Kesehatan Kab.Sleman Tahun 2005, Thesis, Undip, Semarang.

Sukowinarsih, ET, 2010, Hubungan Sanitasi Rumah dengan Angka Bebas Jentik Aedes Aegypti, KEMAS, Vol. 6, No. 1, Tahun 2010, Hal. 3035 .

Widiarti, dkk, 2009, Deteksi Antigen Virus Dengue pada Progenl Vektor Demam Berdarah dengan Metode Imunohistokimia, Buletin Penelitian Kesehatan, Vol. 37, No. 3, Tahun 2009, Hal. 126-136.

Wuryanto, MA, 2008, Surveilans Penyakit Demam Berdarah Dengue (DBD) dan Permasahannya Di Kota Semarang Tahun 2008, Disajikan pada Seminar Nasional Mewujudkan Kemandirian Kesehatan Masyarakat Berbasis Preventif dan Promotif, 13 Maret 2010, Semarang. 
